\title{
Acknowledgements and conventions
}

This book was produced as a result of the Stuart Successions Project, a collaboration between the universities of Exeter and Oxford, funded by the Arts and Humanities Research Council. We wish to thank the universities, and especially the AHRC, for their support. We also acknowledge the contributions of other project team members: Paulina Kewes, Joseph Hone and Anna-Marie Linnell. And we note that the Stuart Successions Project was conceived and developed in collaboration with the late Kevin Sharpe. Although Kevin died - too young shortly after the grant was awarded, the project was greatly indebted to his work. As a friend and colleague, he is greatly missed.

In our annotation of the texts, we benefited from generous advice from a number of people, including Alastair Bellany, Daniel Cattell, David Colclough, Karen Edwards, Neil Guthrie, Joseph Hone, Paulina Kewes, Gerald Maclean and Philip Schwyzer.

This anthology is designed to be compatible with other outputs from the Stuart Successions Project. These include a volume of essays, Literature of the Stuart Successions, ed. Paulina Kewes and Andrew McRae (Oxford: Oxford University Press, forthcoming); and an open-access database of Stuart succession literature, http://stuarts.exeter.ac.uk/database/. We have also developed the website 'Stuarts Online' (http://stuarts-online.com/) to support education in this rich field.

Spelling and punctuation have been modernized lightly in all texts, in order to improve the experience of reading but with a view to retaining the authors' original intentions. All references to the Bible are to the Authorized (King James) Version. 